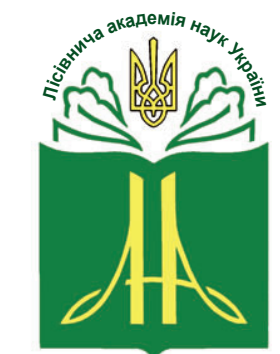

Forestry Academy of Sciences of Ukraine
Наукові праці Лісівничої академії наук України Proceedings of the Forestry Academy of Sciences of Ukraine http://fasu.nltu.edu.ua https://doi.org/10.15421/412003

Article received 2019.12.15

Article accepted 2020.06.04
ISSN 1991-606X print

ISSN 2616-5015 online

(a) $\square$ Correspondence author

Iryna Rusyn rib7@i.ua
Stepan Bandera st., 12, Lviv, 79013, Ukraine

УДК 606:621.3+ 620.951/952+574.46

\title{
Біоелектрика екосистем лісів, заболочених лук та агроекосистем Західної України
}

\author{
І.Б. Русин ', О. В. Медведєв², Б. Т. Валько ${ }^{3}$, С. В. Нікітчук ${ }^{4}$
}

Отримання біоелектрики з екосистем живих рослин та асоиійованих з ними електрогенерувальних трунтових мікроорганізмів є інноваційним джерелом альтернативної енергї. In situ здійснено оцінку біоелектропродуктивності екосистем лісових масивів, заболочених луків та агроекосистем Західної Украӥни у трьох зонах - північній (Полісся), центральній (Опілля) та південній (межа Покутсько-Буковинських Карпат $і$ Чорногори). Найвищі показники біоелектрики трунту зафіксовано у фітомікробоценозах лісів. Середній рівень біоелектричного потенціалу в лісах становив 1080,5 мB. Тільки дещо нижчими були середні біоелектричні показники в садах $і$ заболочених луках, 1055,3 мB і 1051,2 мB, відповідно. Біоелектричний потенціал агрокультур істотно нижчий, за винятком Zеа тауs L. Добовий рівень біоелектрики змінюється незначно із несуттєвим зниженням наприкінці світлового дня в частини зразків. Сезонні коливання рівня біоелектричного потенціалу від початку літа до пізньої осені у досліджених мікробно-рослинних асоціаціях є статистично незначними. Досліджено вплив вологості на генерацію біоелектричного потенціалу фітомікробоценозами. Виявлено позитивний вплив вологості грунту на генерування біоелектричного потенціалу. Встановлено зростання біоелектричного потенціалу в сухих грунтах, зумовлене активним фотосинтезом та акумуляцією вологи рослинами. Отримані результати розкривають перспективи лісових екосистем, екосистем заболочених луків і деяких агроекосистем як джерел поновлюваної та зеленої енергії при подальшому розробленні електробіотехнологічних аспектів.

Ключові слова: рослини; трунтові мікроорганізми; трунт; біоелектричний потенціал; біоелектрохімічна енергія; електроди; відновлювальна енергетика.

Вступ. Екосистемна карта Західної України представлена мозаїкою лісів, земель сільськогосподарського призначення та заболочених територій, що простягаються на сотні гектарів. Крім без- посереднього еколого-географічного, кліматичного, геологічного, рекреаційного та сільськогосподарського значення ці екосистеми можуть слугувати екологічним джерелом біоелектрики, отриман-

\footnotetext{
Русин Ірина Богданівна - кандидат біологічних наук, доцент кафедри екології та збалансованого природокористування Інституту сталого розвитку ім. В'ячеслава Чорновола. Національний університет «Львівська Політехніка», вул. Степана Бандери, 12, м. Львів, 79013, Україна. Тел.:+38-098-435-67-01. E-mail: rib7@i.ua ORCID: http://orcid.org/0000-0002-6041-1245

2 Медведєв Олександр Валентинович - провідний інженер-конструктор філії «Науково-дослідний інститут автомобілебудування “Еталон”», вул. Городоцька, 174, Львів, 79022, Україна. Тел.:+38-067-337-10-17. E-mail:mov2@ukr.net ORCID: https://orcid.org/0000-00020824-9893

3 Валько Богдан Тарасович - магістр кафедри екології та збалансованого природокористування Інституту сталого розвитку ім. В'ячеслава Чорновола. Національний університет «Львівська Політехніка», вул. Степана Бандери, 12, м. Львів, 79013, Україна. Тел.:+38-093-70949-29. E-mail: valkobogdan@mail.ru

4 Нікітчук Сергій Вікторович - магістр кафедри екологічної безпеки та природоохоронної діяльності Інституту сталого розвитку ім. В'ячеслава Чорновола. Національний університет «Львівська Політехніка», вул. Степана Бандери, 12, м. Львів, 79013, Україна. Тел.:+38-063-074-85-31. E-mail: nikitchyk2015@i.ua
} 
ня якої відбувається без заподіяння будь-якої шкоди довкіллю, що властиво традиційним джерелам енергетики. Суть альтернативного методу отримання біоелектрики, що активно розвивається впродовж останнього десятиліття, полягає у внесенні електродних систем у товщу грунту, де ростуть рослини (De Schamphelair et al., 2008; Kaku, Yonezawa, Kodama, \& Watanabe, 2008; Strik, Hamelers, Snel, \& Buisman, 2008). Електроди акумулюють біоелектрику, продуковану грунтовими мікроорганізмами, що живляться кореневими виділеннями продуктів фотосинтезу рослин та продуктами розкладу листяного опаду (Strik et al., 2008; Timmers et al., 2012; Nitisoravut \& Regmi, 2017). В утворенні біоелектрики важливу роль відіграють протони, які виділяються мікроорганізмами внаслідок як розкладу органічних сполук, так і дисоціації вугільної кислоти, утвореної з $\mathrm{CO}_{2}$. Вуглекислий газ виділяється у великих кількостях коренями у грунт в процесі дихання рослин та в процесі метаболізму грунтових мікроорганізмів (Strik et al., 2008). Мікроорганізми, що беруть участь в утворенні біоелектрики, називають електроактивними чи електрогенерувальними (Kim et al., 2004; Logan \& Regan, 2006; Logan, Rossi, Ragab, \& Saikaly, 2019).

Біоелектротехнологічні установки, встановлені в лісах та заболочених територіях, мають перспективи використання для живлення польових автономних систем моніторингу за екосистемами, для влаштування бездротових станцій «зеленого» туризму в природних парках з можливістю підзарядки приладів. Біоелектротехнологічні пристрої, вмонтовані в землях сільськогосподарського призначення, можуть живити автономні системи поливу та давачі вологості грунту, інноваційні системи моніторингу за складом грунту та ростом рослин у межах розумного господарства. За розрахунками нідерландських науковців, теоретичним максимумом рослинно-мікробної електробіотехнології є повне енергозабезпечення цілих оселищ, який можна буде досягнути за умови вдосконалення технологіï (Strik et al., 2011; Wetser, 2016).

Дослідження біоелектрики болотних екосистем у лабораторних умовах показують вагомі перспективи таких об'єктів як важливого джерела біологічної енергії (Liu, Song, Li, \& Yang, 2013; Lu, Xing, \& Ren, 2015; Wetser, Liu, Buisman, \& Strik, 2015). Причина полягає в тому, що заболочені умови створюють оптимальні умови для акумулювання грунтової біоелектрики (Lovley et al., 2011; Helder, Strik, Hamelers, \& Buisman, 2012). Низький вміст кисню в болотистих субстратах зменшує втрати акумульованої біоелектрики. У цьому разі генеровані мікроорганізмами протони та електрони працюють на виробництво енергії, а не на відновлення кисневмісних сполук. Проте досліджень 3 отримання біоелектрики in situ на заболочених територіях є небагато. Перші дослідження електропродуктивності було здійснено безпосередньо на рисових плантаціях Японії (Kaku et al., 2008; Takanezawa, Nishio, Kato, Hashimoto, \& Watanabe, 2010) та продовжено in situ в експериментах на рисових полях Японії та Індонезії (Kouzuma, Kaku, \& Watanabe, 2014; Ueoka, Sese, Sue, Kouzuma, \& Watanabe, 2016; Sudirjo, Pim de Jager, Cees, Buisman, \& Strik., 2019), а також в заболочених лісах Південної Кароліни, США in situ (Dai, Wang, Chow, \& Conner, 2015).

Потенціал та перспективи електропродуктивності екосистем заболочених луків у східноєвропейських кліматичних умовах залишається недослідженим, як і незаболочених територій лісів та сільськогосподарських угідь, представляючи значний інтерес 3 погляду можливого їх багатопланового використання як джерела рослинно-мікробної енергії. Тому вкрай актуальним є завдання оцінювання in situ біоелектричного потенціалу, генерованого численними у Західній Україні як заболоченими, так і незаболоченими екосистемами лісових масивів, луків, земель сільськогосподарського призначення як альтернативних місць для застосування електробіотехнології в ролі джерела зеленої енергії.

Об'скти та методика досліджень. Об'єктами досліджень є біоелектричні параметри найпоширеніших екосистем у Західній Україні: лісових масивів, заболочених луків, сільськогосподарських садів та посівів сільськогосподарських культур (рис. 1). Експерименти проводили у с. Волощина Перемишлянського р-ну Львівської обл. (Опілля), с. Прилісне Маневицького p-ну Волинської обл. (Полісся) та с. Кривопілля Верховинського р-ну Івано-Франківської обл. (на межі ПокутськоБуковинських Карпат і Чорногори) (рис. 2). Всього було проаналізовано 32 найпоширеніші види мікробно-рослинних асоціацій по 50 зразків кожного виду.

Предметом досліджень є добові та сезонні коливання біоелектричного потенціалу. Meта дослідження - визначити біоелектричний потенціал рослинно-мікробних асоціацій екосистем, який вимірювали in situ.

Біоелектричний потенціал визначали у мікробно-рослинних асоціаціях Pinus silvestris L. та Quercus robur L., які є панівними деревними видами у лісах України, а також у мікробно-рослинних асоціаціях Fagus sylvatica L., Betula pendula Roth., Alnus glutinosa (L.) Gaerth. та Carpinus betulus L., частка яких також досить значна у видовому складі лісових масивів України (Bodnar, 2016). Діаметр стовбурів дерев у середньому становив 0,25-0,47 м. Ірунт біля досліджуваних деревних видів вкритий шаром опалого листя чи хвої, мохом або трав'яними рослинами.

Об’єктами досліджень в агроекосистемах є показники біоелектрики типових мікробно-рослинних асоціацій фруктових садів: плодових дерев та кущів, за участі низки компонентів, зокрема, деревних видів Prunus cerasus L., Prunus domestica L., Malus domestica Borkh., Pyrus communis L., Juglans regia L. 3 діаметром стовбура в середньому 0,100,35 м; кущових видів Ribes nigrum L., Ribes rubrum L., Rubus idaeus L., Ribes uva-crispa L. заввишки в середньому 1,32-1,95 м; окремих особин Viburnum 
opulus L. заввишки 2,58-3,42 м, Vitis vinifera L. завдовжки в середньому 1,74-3,04 м; а також однорічних сільськогосподарських культур - як низькорослих (Allium сера L., Petroselinum cripsum (Mill.)
Fuss, Daucus carota subsp. sativus, Beta vulgaris L., Brassica oleracea L., Cucurbita pepo var. giraumontia, Cucurbita pepo L.), так і високорослих (Cucumis sativus L., Capsicum annuum L. та Zea mays L.).
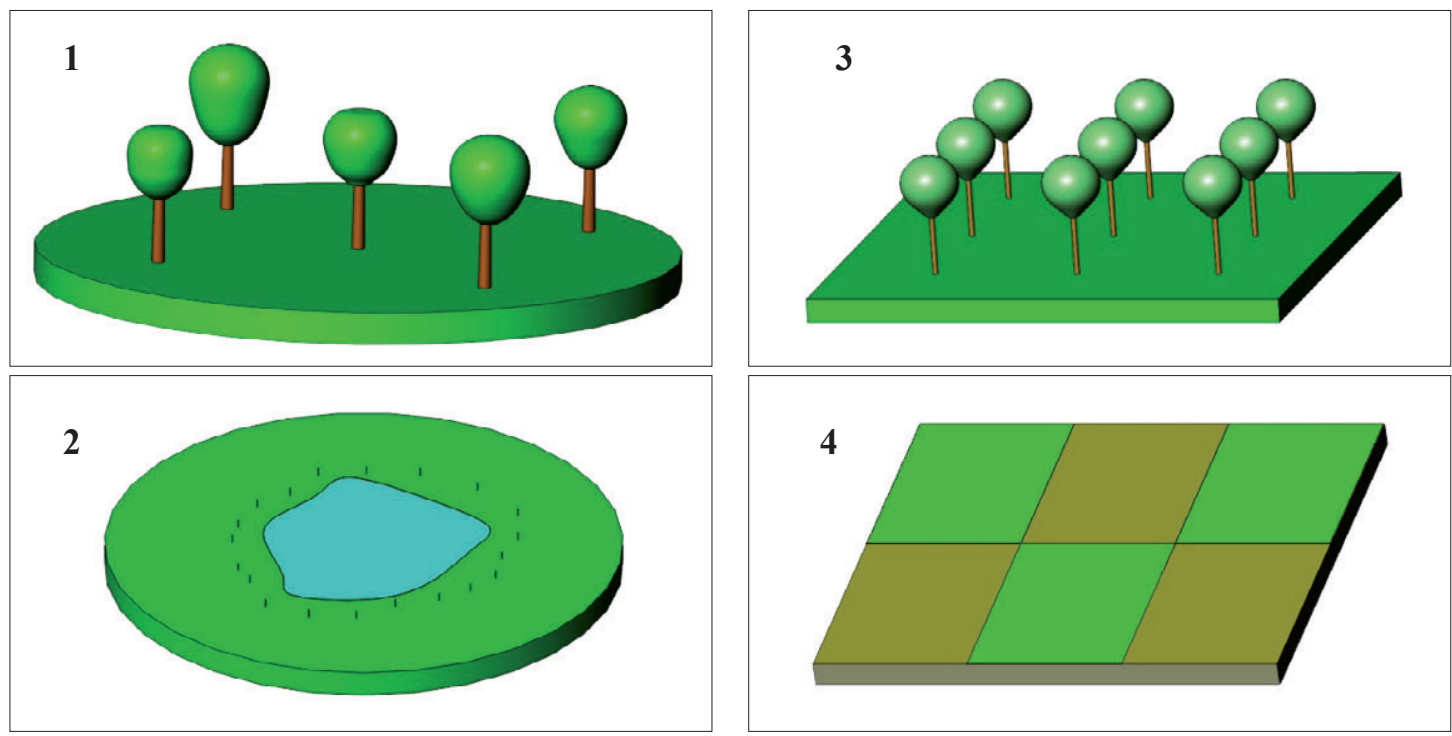

Рис. 1. Схематичне подання типів експериментальних ділянок моніторингу за біоелектричним потенціалом екосистем: лісів (1), заболочених луків (2), плодових садів (3) та посівів сільськогосподарських культур (4)

В екосистемах заболочених луків вивчали біоелектричні параметри фіто-мікробоценозів за участю Carex hirta L., Carex brizoides L., Scirpus lacustris L., Poa palustris L. та Caltha palustris L.

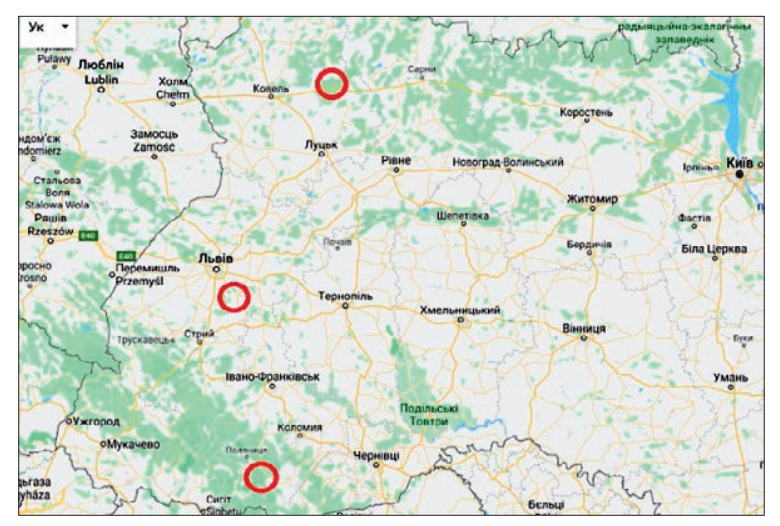

Рис. 2. Місця проведення експериментів у Західній Україні, в межах яких стаціонарно вмонтовано електродні системи для спостережень за біоелектричними параметрами

Для реєстрації біоелектричного потенціалу використовували розроблену нами моноелектродну систему (Rusyn \& Medvediev, 2016) із графітових катодів, розміром $90 \times 30 \times 15$ мм та оцинкованостальних або алюмінієвих анодів, розміром $292 \times 30 \times 0,8$ мм або $300 \times 0,3 \times 0,3$ мм, відповідно, 3 під'єднаними до них полівінілхлорид-ізольованими мідними дротами. Електродну систему розташовували стаціонарно на певній глибині у грунті - безпосередньо в зоні асоціації рослинного коріння та мікроорганізмів, де відбувається вивільнення електронів та протонів (рис. 3).

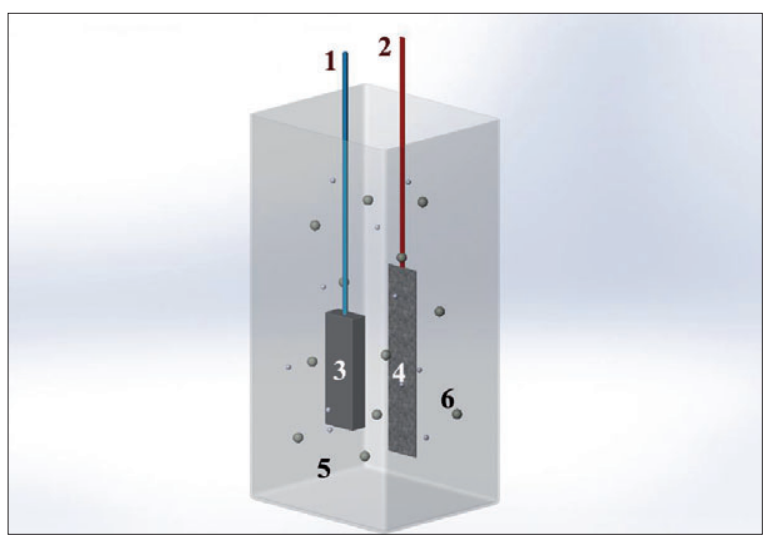

Рис. 3. Схематичне зображення використання електродів для визначення біоелектричного потенціалу у грунтах в найактивнішій зоні взаємодії коренів рослин та мікроорганізмів: 1 - вихід дроту, що з'єднує катод; 2 - вихід дроту, що з'єднує анод; 3 - катод; 4 - анод; 5 - субстрат; 6 - грунтові електроактивні мікроорганізми

Закінчення мідних дротів виводили на грунтову поверхню. Катоди та аноди поміщали на встановленій експериментально оптимальній дистанції між електродами 0,15 м та на відстані $0,5-1,0$ м від стовбура; в частині експериментів - на відстані 0,5-3,0 м та 0,1-0,3 м від стебла рослини і на глибині 0,3-0,4 м у товщі грунту, де зосереджена основна маса кореневої системи як лісових, так і польових рослин (Zinchenko, Salatenko, \& Bilonozhko, 2001; Crow, 2005; Eshel \& Beeckman, 2013). За допомогою цифрового мультиметра, щупи якого закріплювали на дротах, що виходили на поверхню грунту 3 його глибини, знімали покази біоелектричного потенціалу. Покази біоелектричного потенціалу 
реєстрували в чотирьох різних ділянках біля одного об'єкта, оскільки кореневі системи можуть бути асиметричними (Ganatsas \& Spanos, 2005). Біоелектричні параметри вимірювали тричі на добу впродовж 150 днів (з червня по жовтень 2014 р.) та вираховували їхнє середнє значення. Наведені в роботі результати представлені як середнє значення для всіх повторюваних експериментів та їх стандартні похибки ( \pm SE). Статистичну оцінку істотності різниці між середніми значеннями обчислено за допомогою F-тесту для 95\%-го рівня достовірності.

Результати та обговорення. Експерименти, здійснені in situ у різних частинах Західної України впродовж 150 днів, показали досить високі значення отримуваної біоелектрики у найпоширеніших рослинно-мікробних асоціаціях - лісових масивах, заболочених луках та садових територіях, i дещо нижчі - на орних землях 3 насадженнями агрокультур. Середній рівень біоелектричного потенціалу в лісах становив 1080,5, у садах - 1055,3, заболочених луках - 1051,2 та в агрокультурах - 974,4 мВ (рис. 4).

Пояснення щодо зафіксованих саме у лісових фітоценозах найвищих показників біоелектрики грунту може полягати у поєднанні дії значної кількості чинників, основними з яких $є$ такі. Лісові рослинномікробні асоціації є стабільними, сформованими впродовж тривалого часу та стабільно функціонуючими впродовж багатьох десятків років. У лісах відсутня щорічна механічна дія на грунт, властива землям сільськогосподарського призначення, що руйнує рослинно-мікробні зв'язки. Великий розмір лісових дерев, що сягають багато метрів у висоту, їхня значна фотосинтетична поверхня крони зумовлюють більшу кількість речовин, яку вони можуть віддавати через коріння у навколишнє середовище, ніж менші за розміром рослини, і цим самим інтенсивніше стимулювати розвиток грунтових мікроорганізмів. Більшість деревних рослин мають потужно розвинену горизонтальну частину кореневої системи (Kalinin, Huz, \& Debryniuk, 1998; Maliuha \& Khryk, 2010; Eismont, 2014), локалізовану в товщі грунту до 30-60 см від поверхні (Dobson, 1995; Crow, 2005; Eshel \& Beeckman, 2013). Так, наприклад, корені $Q$. robur можуть проникати на глибину понад 15 м, однак горизонтальне тонке коріння, важливе для живлення електрогенерувальних мікроорганізмів, зосереджене на глибині 15-40 см (Kalinin, Huz, \& Debryniuk, 1998; Mauer, Houskova, \& Mikita, 2017). Глибина проникнення коріння P. silvestris може сягати понад 10 м, однак на бідних сухих грунтах сосна формує потужну поверхневу кореневу систему 3 короткими дрібними корінцями, зазвичай з мікоризою (Munzenberge, Golldack, Ullrich, Schmincke, \& Huttl, 2004; Aucina et al., 2007; Raudaskoski \& Salo, 2008). Значна частина коріння сосни зосереджена на глибині до 20 см (Ganatsas \& Spanos, 2005; Maliuha \& Khryk, 2010). Коренева система $A$. glutinosa та B. pendula теж розташована здебільшого поверхнево (Zuzuk, Kutsyk, Radko, Kulahina, \& Serbin, 2007; Ostonen et al., 2013) і часто пов' язана мікоризою (Baxter \& Dighton, 2001).
Органічні виділення приповерхневого горизонтального коріння дерев $є$ істотними для створення мікроорганізмами біоелектричного потенціалу. Крім того, у лісах зосереджений значний обсяг органічного опаду, який є джерелом поживних речовин для розвитку електропродукувальних мікроорганізмів. Мікориза, що «сполучає» дерева в лісі між собою та простягається на багато кілометрів під землею, розподіляючи ресурси між лісовими деревами (Simard et al., 2015), створює оптимальні умови для розвитку мікроорганізмів, які генерують електричний потенціал. На наш погляд, саме тому у лісових екосистемах зафіксовано найвищі значення біоелектрики.

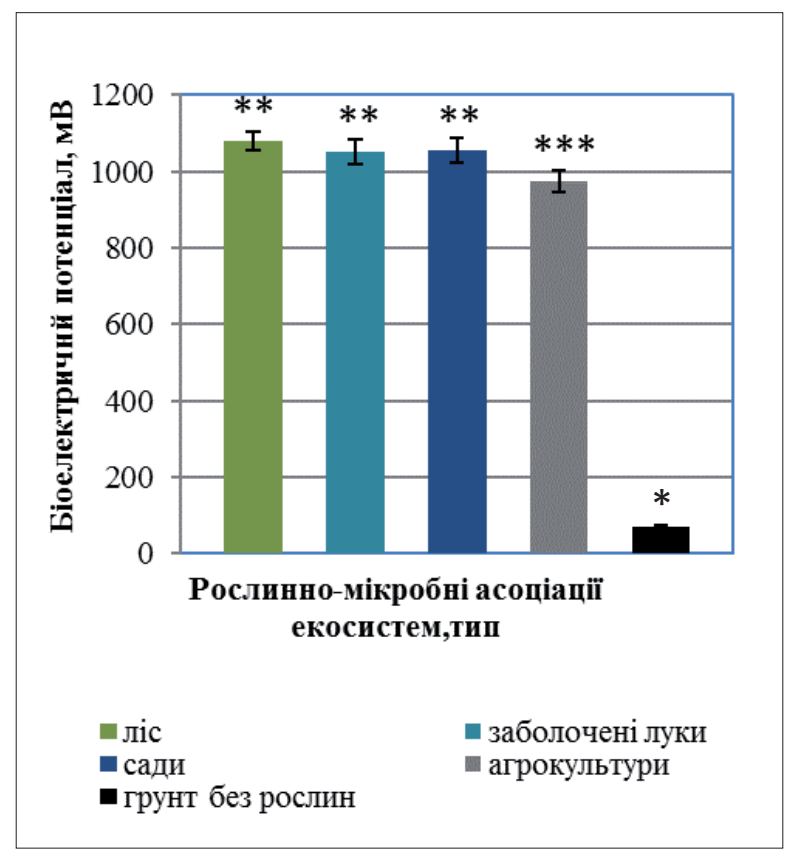

Рис. 4. Біоелектрика мікробно-рослинних асоціацій екосистем лісів, заболочених луків, фруктових садів, агрокультур та грунту без рослин (контроль), впродовж

150 днів спостережень протягом червня-жовтня $(\mathrm{x} \pm \mathrm{SE}, \mathrm{n}=50)^{1}$

Перераховані вище численні сприятливі умови для створення мікроорганізмами біоелектричного потенціалу в лісових масивах компенсуються наявними недоліками менш сприятливих умов для акумулювання біоелектрики, порівняно із заболоченими територіями. Тому, з удосконаленням технології «збору електрики грунтів», лісові мікробо-рослинні асоціації можуть стати важливим джерелом альтернативної енергії для поселень Волинського Полісся та лісових регіонів Карпат.

1 1. Біоелектричний потенціал грунту без рослин суттєво відрізняється порівняно з іншими рослинними екосистемами $(\mathrm{P}<0.05)$.

2. Між біоелектричними параметрами екосистем лісу, заболочених луків і фруктових садів статистично суттєва різниця відсутня $(\mathrm{P}>0.05)$.

3. Різниця між біоелектричними параметрами фітомікробоценозів агрокультур та екосистем лісу є статистично істотною $(\mathrm{P}<0.05)$ 
Зафіксований високий середній біоелектричний потенціал у садових фітоценозах та заболочених луках є дещо нижчим, ніж у лісах (P > 0,05, $\mathrm{p}>0,516$ та $\mathrm{p}>0,492$ відповідно), оскільки садові агроекосистеми наближені за умовами для розвитку електрогенерувальних мікроорганізмів до лісових, а в болотних екосистемах наявні найкращі умови для нагромадження біоелектрики (Lovley et al., 2011; Helder et al., 2012). Поряд 3 цим, у деяких садових і заболочених екосистемах зафіксова- но досить високі значення біоелектричного потенціалу, і навіть вищі від середніх значень біоелектрики лісових екосистем, що підтверджує перспективи використання цих територій як джерела біоелектрики.

Так, середній біоелектричний потенціал садових мікробно-рослинних асоціацій фруктових кущів $R$. idaeus на 90-й та 91-й дні експерименту становив 1220,9 мВ, а екосистем заболочених луків 3 C. hirta-1111,8 мB (рис. 5).

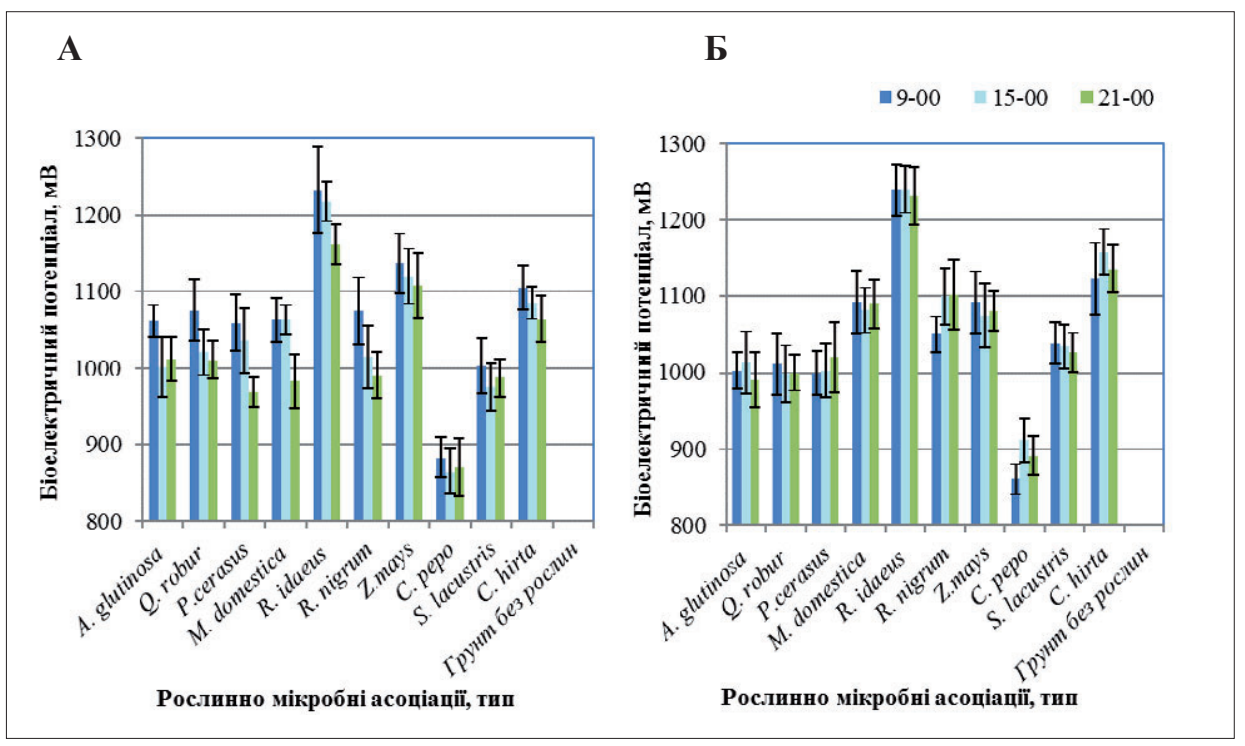

Рис. 5. Добові коливання біоелектричного потенціалу мікробно-рослинних асоціацій у лісових екосистемах A. glutinosa і Q. robur, екосистемах фруктових садів P. cerasus і M. domestica, ягідних кущів $R$. idaeus і $R$. nigrum, агрокультур Z. mays і C. pepo, екосистем заболочених луків $S$. lacustris i $C$. hirta та грунту без рослин як контролю на 90-й день експерименту (А) та 91-й день експерименту (Б) (x $\pm \mathrm{SE}, \mathrm{n}=50)$.

Величина біоелектричного потенціалу грунту без рослин становить $68,7 \pm 3,0$ мВ (А) та 66,3 22,4 мВ (Б)

Середній рівень біоелектричного потенціалу агроекосистем сільськогосподарських рослин, порівняно $з$ лісовими екосистемами, нижчий у середньому на 106,1 мB $(\mathrm{P}<0,05, \mathrm{p}>0,995)$. Таке явище можна пояснити тим, що на орних землях відсутні сформовані багаторічні симбіотичні зв'язки між рослинами та грунтовими бактеріями, наявними у лісах, садах, луках, сінокосах та пасовищах, оскільки орні землі декілька разів на рік зазнають механічного впливу (оранка, культивація, боронування тощо), а інокуляція біодобривами малопоширена. Внаслідок таких заходів ефективність надходження кореневих виділень, насичених необхідними речовинами для розвитку електрогенерувальних мікроорганізмів, є нижчою. Рослинний опад, що слугує ще одним джерелом поживних речовин для розвитку мікроорганізмів, відсутній в екосистемах сільськогосподарських культур. Крім цього, активне використання різних пестицидів, гербіцидів та хімічних добрив в умовах неорганічного землеробства пригнічує ріст мікроорганізмів. Вимивання кореневих виділень, важливих для генерації біопотенціалу та розподіл їх по вертикальному профілю відбувається інтенсивніше на грунтах, де немає стабільно функціонуючих потужних кореневих систем.
Винятком серед агроекосистем, що характеризуються низькими значеннями біоелектрики, $\epsilon$ біоелектрична продуктивність насаджень кукурудзи, яка є високопродуктивною культурою, здатною за короткий час нагромадити більше органічної маси, ніж інші культурні рослини (Mokriienko $\&$ Tsentylo, 2011). Фотосинтетична поверхня кукурудзи перевищує більшість агрокультур, що $є$ причиною активного живлення електрогенеруючих мікроорганізмів. Очевидно, через зазначені вище причини біоелектричний потенціал кукурудзи $є$ на рівні екосистем садових кущів та дерев та в середньому становить 1102,5 мВ (див. рис. 5).

Добові коливання продукування біоелектрики усіх проаналізованих екосистем $є$ не істотними $(\mathrm{P}>0,05, \mathrm{p}>0,943)$ (див. рис. 5). Так, наприклад, середня добова різниця між максимальним та мінімальним значеннями біоелектричного потенціалу, що спостерігалася впродовж 90-го та 91-го днів експерименту, становить 48,38 мВ.

У динаміці коливань біоелектричного потенціалу рослинно-мікробних асоціацій екосистем упродовж доби спостерігається два основні аспекти: 1) найвищі значення біоелектрики зафіксовано зранку о 9.00 та в другій половині дня (15.00 год), 
а наприкінці дня (21.00 год) встановлено деяке зниження рівня біоелектричного потенціалу (див. рис. 5A); 2) рівень біоелектрики залишається загалом подібним упродовж дня, а різниця біоелектричного потенціалу становить тільки 22,91 мВ (див. рис. 5Б). Добова різниця біоелектричного потенціалу між ранковим та вечірнім значеннями становить в середньому 50,94 мВ на 90-й день експерименту. У деяких фітоценозах виявлено дещо вищу різницю біоелектричного потенціалу впродовж дня. Так, наприклад, зафіксоване значення біоелектричного потенціалу мікробно-рослинної асоціації P. cerasus зранку вище від виявленого наприкінці дня на 90,7 мB, а $R$. nigrum - на 83,7 мB.

Подібні результати подано в дослідженнях Nguyen \& Nitisoravut (2019), які повідомляють, що вихід біоелектрики $\epsilon$ вищим упродовж світлого, порівняно $з$ темним періодом доби. На нашу думку, це явище пов'язано $з$ процесом фотосинтезу. У світлову частину доби рослини активно виділяють у грунт асиміляти та інші метаболіти, які використовують для своєї життєдіяльності грунтові мікроорганізми. Рівень фотосинтезу та, відповідно, нагромадження органічних сполук для розвитку електроактивних мікроорганізмів, що залежить від погодних умов та фізико-хімічних властивостей грунту, $\epsilon$ специфічними для кожної екосистеми у світлову частину доби, тому і спостерігаються невеликі коливання рівнів біоелектричного потенціалу.

Експерименти 3 вивчення впливу вологості грунту на рівень біоелектрики in situ демонструють дещо інші результати, ніж отримані у сконструйованих лабораторних екосистемах, де встановлена пряма залежність впливу вологості грунту на електропродуктивність (Nguyen \& Nitisoravut, 2019). Природні екосистеми $€$ значно складнішими, ніж змодельовані та зазнають впливу більшої кількості чинників, які неможливо відтворити у лабораторних умовах. Незважаючи на те, що вологі субстрати $\epsilon$ значно кращим середовищем для акумулювання біоелектрики, ніж недостатньо зволожені, проте низка перелічених вище оптимальних чинників для розвитку електроактивних мікроорганізмів у лісах і фруктових садах компенсують певну сухість грунту та забезпечують значення біоелектричного потенціалу на рівні вологих місцезростань (див. рис. 4). У деяких екосистемах із сухими грунтами (до $30 \%$ вологості) спостерігався рівень біопотенціалу на рівні $з$ вологими (31-70\%) та мокрими (71-100\%) грунтами або навіть вищим (див. рис. 4). Середній біоелектричний потенціал лучних мікробно-рослинних асоціацій, для яких характерна висока вологість грунту, $є$ навіть дещо нижчим від біоелектричного потенціалу лісів 3 невисокою вологістю грунту. Так, біоелектричний потенціал лісової мікробно-рослинної асоціації A. glutinosa (рис. 6) суттєво не відрізняється від такої у $Q$. robur (рис. 7) на 70-й день експерименту та становить $1001,3 \mathrm{mB}$ проти 1010,3 мB (P > 0.05), хоча перші дані отримані зі сухого грунту із вмістом вологи $15 \%$, а наступні - із грунту з вологістю $45 \%$.
Водночас трапляються випадки, коли в тих самих зразках за однакової вологості грунту (10-20\%), чи за зниження вологості, біоелектричний потенціал суттєво зростає впродовж кількох днів $(\mathrm{P}<0,05)$.

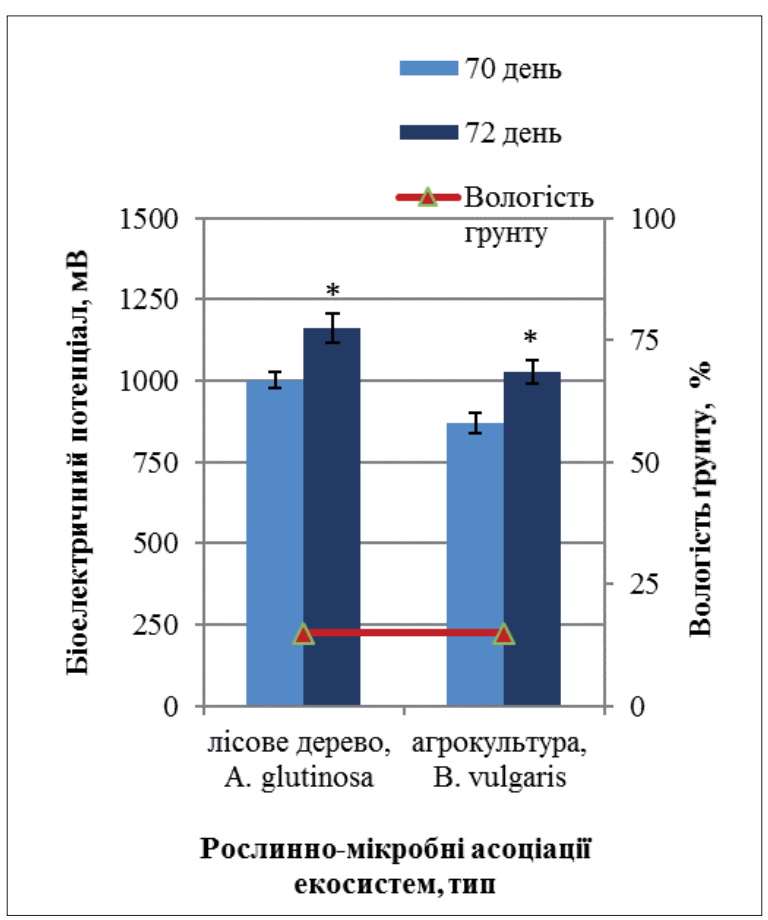

Рис. 6. Біолектричний потенціал мікробно-рослинних асоціацій лісу та агрокультур за однакової вологості грунту (15\%) на 70-й та 72-й дні експерименту $(\mathrm{x} \pm \mathrm{SE}, \mathrm{n}=50)$. [Рівень біоелектричного потенціалу істотно зростає на 72-й день $(\mathrm{P}<0.05)]$

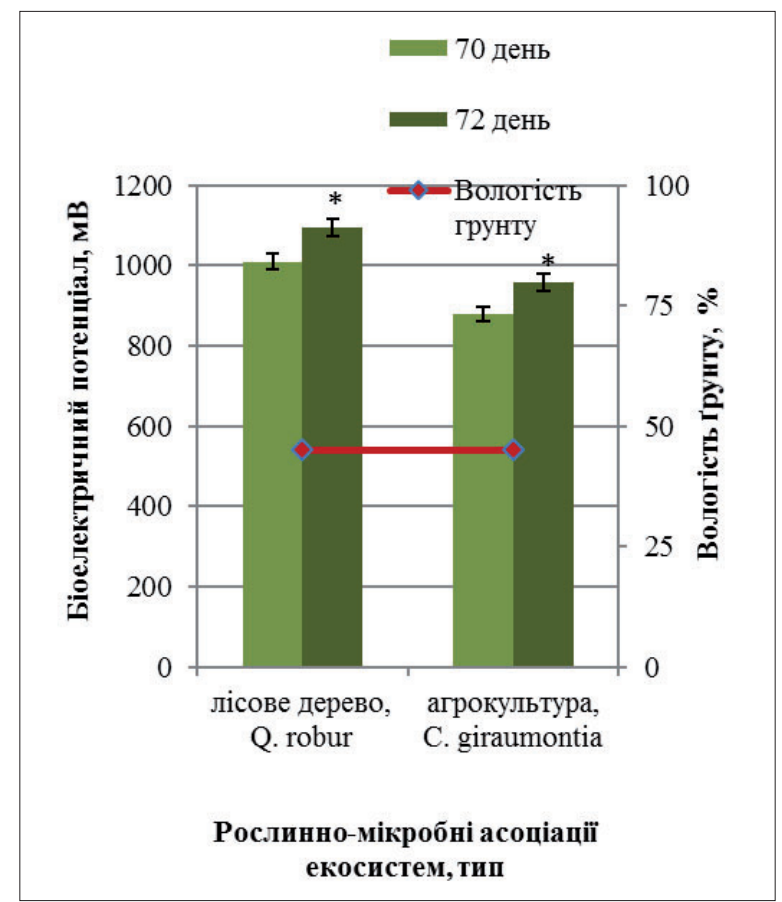

Рис. 7. Біолектричний потенціал мікробно-рослинних асоціацій лісу та агрокультур за однакової вологості грунту (45\%) на 70-й та 72-й дні експерименту $(\mathrm{x} \pm \mathrm{SE}, \mathrm{n}=50)$. [Рівень біоелектричного потенціалу істотно зростає на 72-й день $(\mathrm{P}<0.05)]$ 
Наприклад, суттєве зростання рівня біоелектрики спостережено в лісових та садових мікробнорослинних асоціаціях A. glutinosa та $B$. vulgaris за однакової вологості грунтових зразків (15\%) на 70-й i 72-й дні експерименту; різниця між рівнем біоелектричного потенціалу становить 160,2 та $155,7 \mathrm{mB}$ $(\mathrm{P}<0,05)$ (див. рис. 6). Подібне явище зафіксовано у вологому грунті (45\%) на 70-й та 72-й дні експерименту у мікробно-рослинних асоціаціях лісу $Q$. robur та агрокультур C. pepo var. giraumontia. Підвищення біоелектричного потенціалу на 72-й день експерименту досить істотне і становить 85,2 та 78,8 мВ, відповідно, незважаючи на відсутність змін у вологості грунту $(\mathrm{P}<0.05)$ (див. рис. 7 ).

За зниження вмісту вологи у грунті від 55\% на 81-й день експерименту до $25 \%$ на 83 -й день, рівень біоелектричного потенціалу також істотно зростає (рис. 8). За цих умов підвищення біоелектричного потенціалу становить 96,3 та 81,7 мB у садових екосистемах та агроекосистемах $R$. rubrum і $B$. oleracea, відповідно $(\mathrm{P}<0,05)$. Ці дані, водночас, $\epsilon$ ще одним доказом мікробно-рослинного походження біоелектрики грунту: таке явище було б неможливим, якщо б електрика грунту була наслідком тільки його катіонно-аніонного складу.

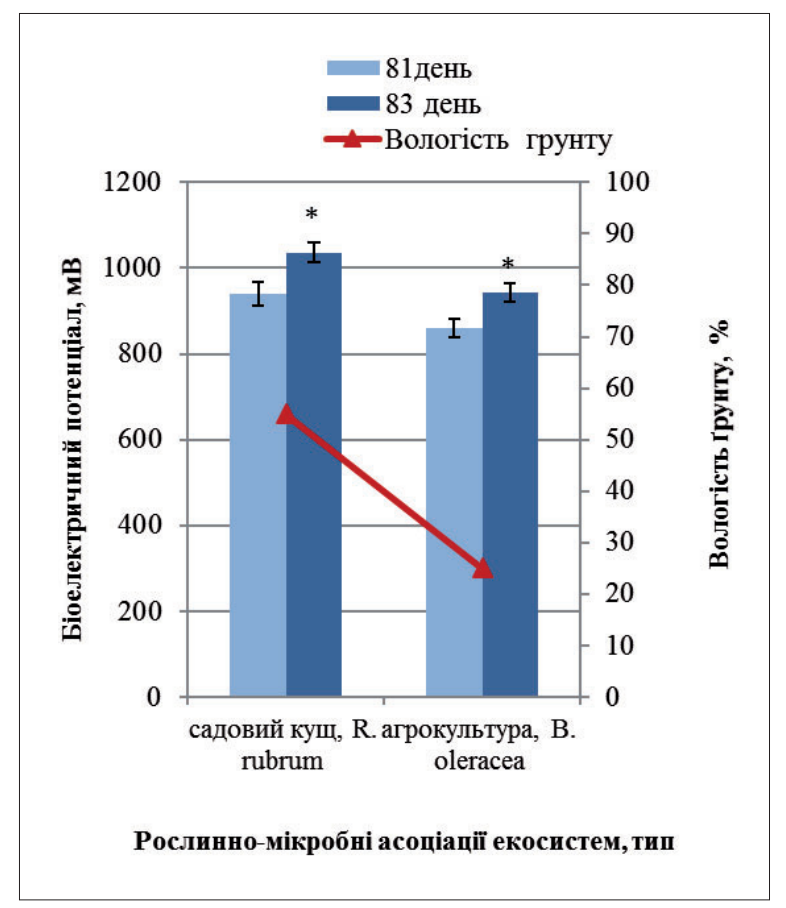

Рис. 8. Біоелектричний потенціал мікробно-рослинних асоціацій саду та агрокультур за зниження вологості грунту від 55\% на 81-й день експерименту до 25\% на 83-й день експерименту $(\mathrm{x} \pm \mathrm{SE}, \mathrm{n}=50)$.

[Рівень біоелектричного потенціалу істотно зростає на 83-й день $(\mathrm{P}<0.05)]$

Високі показники біоелектрики сухих грунтів, коли електропровідність загалом грунту низька, можуть бути наслідком активних рослинних виділень та їх концентрацією у грунті. На відміну від сухих грунтів, у вологих грунтах значно інтенсив- ніше відбуваються метаболічні процеси у рослин та мікроорганізмів, що генерують біоелектрику, але й одночасно за наявності вологи можливе інтенсивне вимивання та розподіл кореневих виділень по всій товщі грунту по вертикальному профілю, а отже, позбавлення грунтових мікроорганізмів ресурсів для генерування біоелектрики. Особливо активним $\epsilon$ процес вимивання в агроекосистемах $-\mathrm{y}$ культурах з відсутнім супутнім рослинним покривом, який утримує дощову воду. Тому за умов дощової погоди в агрокультурах можуть бути зафіксовані невисокі показники біоелектрики, і навіть нижчі, ніж у сухих грунтах.

Виявлений факт високих показників біоелектрики у грунтах із низькою вологістю та їх зростання із зниженням рівня вологи у грунті $€$ ще одним доказом того, що отримувана біоелектрика залежить, насамперед, від активності рослин. Описане вище явище ілюструє і той факт, що за подібних умов вологості і кислотності, грунти з рослинами і без них істотно різняться значеннями біоелектричного потенціалу $(\mathrm{P}<0,05)$ (рис. 9). Середнє значення біоелектричного потенціалу мікробнорослинних асоціацій лісу та саду ( $B$. pendula та D. carota) перевищують потенціал грунту без рослин у 15,5 та 10,5 разів. Високі значення біоелектричного потенціалу у сухому грунті з рослинами та низькі у такому ж сухому грунті без рослин $\epsilon$ свідченням того, що низька вологість (10-20\%) не $\epsilon$ визначальним фактором для розвитку електрогенерувальних мікроорганізмів; вирішальними натомість $\epsilon$ рослини, які постачають електроактивним мікроорганізмам необхідне органічне живлення та вологу.

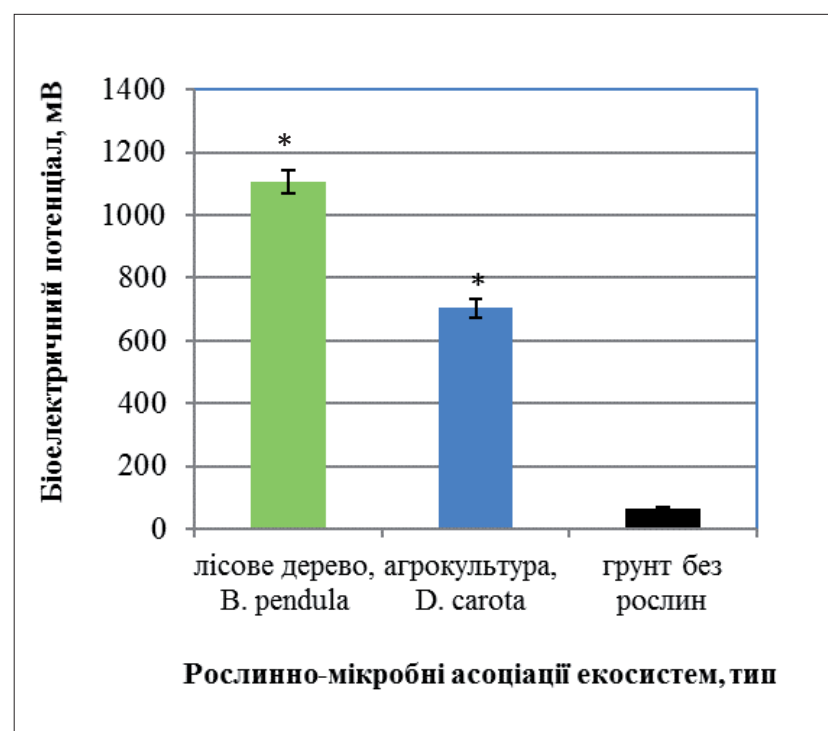

Рис. 9. Біолектричний потенціал мікробно-рослинних асоціацій лісу, агронасаджень та грунту без рослин за умов низького вмісту вологи у грунті $15 \%(\mathrm{x} \pm \mathrm{SE}, \mathrm{n}=50)$. [Середній рівень

біоелектричного потенціалу мікробно-рослинної асоціацій лісу та саду істотно перевищує потенціал грунту без рослин $(\mathrm{P}<0.05)]$ 
Водночас у багатьох екосистемах відмічено позитивний зв'язок між зростанням вологості та біоелектрики (рис. 10). Відомо, що за високої вологості грунту активніше відщеплюються та мігрують заряджені частинки, активніше відбувається фотосинтез. Якщо вологість за певних умов виступає основним чинником впливу на активність екосистеми, то 3 підвищенням вологості грунту електропровідність тільки зростає. Так, за збільшення вологості грунту від 15 до 55\% впродовж 80-87-го днів експерименту істотно зростає і рівень біоелектричного потенціалу лісових та садових мікробно-рослинних асоціацій $(\mathrm{P}<0,05)$. В цих умовах ріст біоелектричного потенціалу лісових мікробно-рослинних асоціацій $P$. silvestris та садових $M$. domestica складає 159,3 та 115,4 мВ, відповідно $(\mathrm{P}<0,05)$ (див. рис. 10).

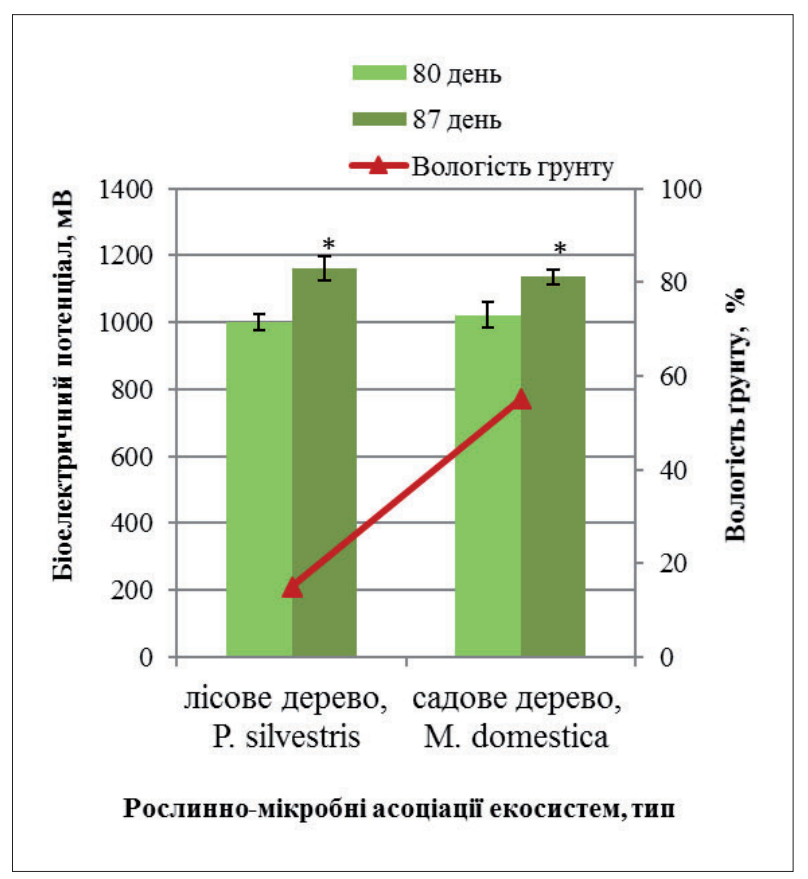

Рис. 10. Вплив вологи на біоелектричний потенціал мікробно-рослинних асоціацій лісу та саду впродовж

80 -го та 87-го днів експерименту $(\mathrm{x} \pm \mathrm{SE}, \mathrm{n}=50)$.

[Зростання біоелектричного потенціалу на 87-й день експерименту є істотним $(\mathrm{P}<0.05)$ ]

Незважаючи на щоденні коливання рівня біоелектрики, пов'язані з багатьма чинниками зовнішнього середовища, сезонні зміни біоелектричного потенціалу $є$ неістотними. Так, наприклад, середній біоелектричний потенціал мікробно-рослинних асоціацій саду $P$. communis та $R$. idaeus, як і екосистем заболочених луків за участю C. brizoides та P. palustris, 1-го та 5-го місяців експерименту відрізнявся неістотно, різниця становила від 34,2 до 60,9 мВ (P > 0,05, p > 0,632, p > $0,770)$ (рис. 11).

Високі і стабільні середні значення біоелектричного потенціалу мікробно-рослинних асоціацій лісів та заболочених луків, фруктових садів та деяких сільськогосподарських культур 3 червня по жовтень, зростання потенціалу навіть у засушливих умовах розкривають їхні перспективи як важливого джерела відновлювальної енергії. Ліси та заболочені території змогли би стати додатковим екологічно чистим джерелом енергії як масштабного, так і локального значення. Біоелектротехнологія може мати високу актуальність для Волинської області, заболочені території якої, за даними Державного агентства лісових ресурсів України, займають найбільшу частку серед усіх областей України - 10,3\% (Hryhora, Vorobiov, \& Solomakha, 2005; Ivchenko, 2007; Bodnar, 2016), а також для північних низовинних територій Полісся та гірських територій України, де частка лісів є досить значною і займає від 40 до 80\% всієї території (Ilina, 2007; Barvinskyi \& Tykhenko, 2015). Підведення ліній електропередач до цих територій є проблематичним, супроводжується великими фінансовими затратами та руйнуванням довкілля. Землі сільськогосподарського призначення, які становлять значну частку в центральних регіонах Західної України, $\mathrm{i}$,

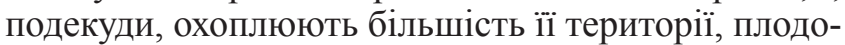
ві сади та агрокультура Zea mays L. могли би використовуватися як джерело біоелектрики. Використання орних земель для енергопотреб мали б короткочасний характер, пов'язаний з терміном вирощування культур та механічною дією на грунт. Натомість, сільськогосподарські сади, сіножаті та пасовища, приватні сади в оселищах, частка яких досить значна у земельному фонді сільськогосподарського призначення (Barvinskyi \& Tykhenko, 2015), могли б експлуатуватися цілорічно як джерело «зеленої» електрики.

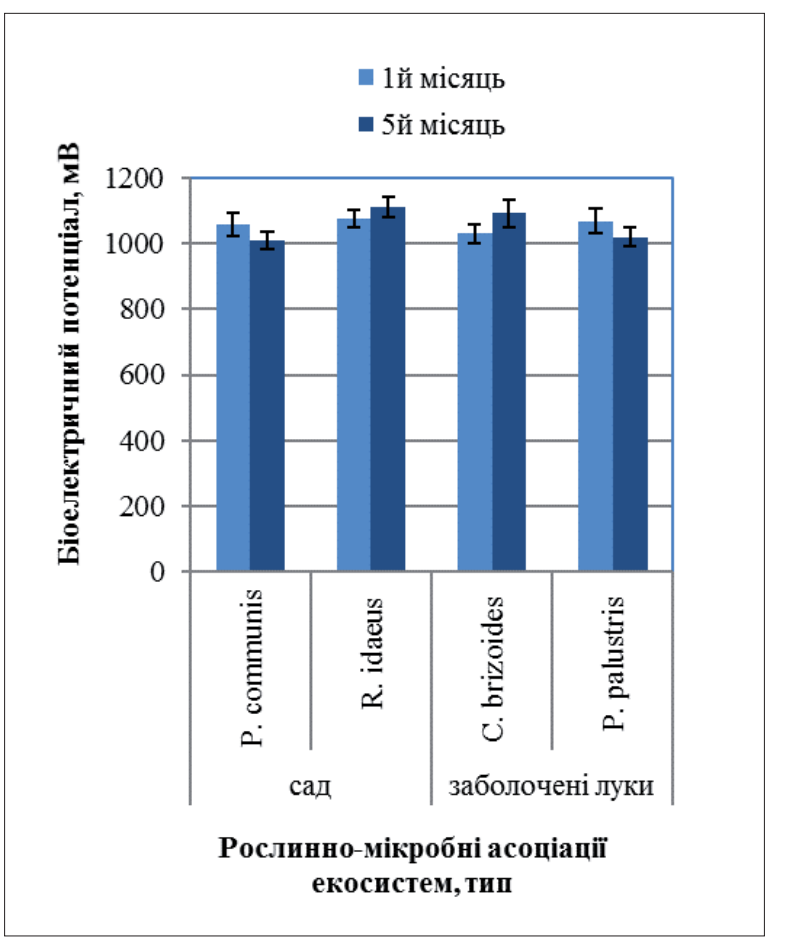

Рис. 11. Середній біоелектричний потенціал болотистих та садових екосистем впродовж 1-го та 5-го місяців експерименту $(\mathrm{x} \pm \mathrm{SE}, \mathrm{n}=50)$ 
Висновки. Екосистеми лісів, заболочених луків та деяких агроекосистем, зокрема насаджень плодових дерев, садових кущів та агрокультур мають потенціал як джерело біоелектрики. Коливання біоелектрики впродовж доби у досліджених мікробнорослинних асоціаціях є несуттєвим. Сезонні коливання рівня біоелектричного потенціалу впродовж червня-жовтня у мікробно-рослинних асоціаціях лісу, заболочених луків, садів та агрокультур $є$ статистично незначними. Для генерування біоелектричного потенціалу необхідний цілий комплекс сприятливих умов температури, вологості та освітлення. Виявлено зростання рівня біоелектричного потенціалу в сухих грунтах за незмінної вологості та за зниженої вологості грунту, що $\epsilon$ наслідком ефективного впливу фотосинтетичної активності рослин на розвиток електрогенерувальних мікроорганізмів. 3 іншого боку, зростання вологості грунту має істотний позитивний вплив на рівень біоелектричного потенціалу. Подальше розроблення електробіотехнологічного напряму відкриває потенційні можливості лісових екосистем, екосистем фруктових садів, екосистем заболочених луків, посівів деяких агрокультур, як джерела поновлюваної та стабільної зеленої енергії.

\section{References}

Akhani, H. (2014). Caltha palustris. The IUCN Red List of Threatened Species 2014: e.T167915A42321925. Retrieved from https://dx.doi.org/10.2305/IUCN. UK.2014-1.RLTS.T167915A42321925.en

Aucina, A., Rudawska, M., Leski, T., Skridaila, A., Riepsas, E., \& Iwanski, M. (2007). Growth and mycorrhizal community structure of Pinus sylvestris seedlings following the addition of forest litter. Applied and enviromental microbiology, 73 (15), 4867-4873. https://doi.org/10.1128/AEM.00584-07

Barvinskyi, A. V., \& Tykhenko, R. V. (2015). Land quality assessment and forecast. Kyiv: Medinform (in Ukrainian).

Baxter, J.W., \& Dighton, J. (2001). Ectomycorrhizal diversity alters growth and nutrient acquisition of grey birch (Betula populifolia) seedlings in host-symbiont culture conditions. New Phytologist, 152, 139-149.

Bodnar, V.O. (2016). General characteristics of forests and forestry of Ukraine. Public report of the State Forest Resources Agency of Ukraine, Kyiv (in Ukrainian). Retrieved from http://dklg.kmu.gov.ua/ forest/control/uk/publish/article?art_id=62921

Crow, P. (2005). The influence of soits and species on tree root depth. Edinburgh: Forestry Commission.

Dai, J., Wang, J.-J., Chow, A.T., \& Conner, W.H. (2015). Electrical energy production from forest detritus in a forested wetland using microbial fuel cells. Global Chance Biology Bioenergy, 7, 244-252. https://doi.org/10.1111/gcbb.12117

De Schamphelaire, L., Van Den Bossche, L., Hai, S. D., Höfte, M., Boon, N., Rabaey, K., \& Verstraete, W. (2008). Microbial fuel cells generating electricity from rhizodeposits of rice plants. Environmental Science \& Technology, 42(8), 3053-3058. https://doi. org/10.1021/es071938w

Dobson, M. (1995). Tree root systems. Farnham: Arboricultural Advisory and Information Service.

Eismont, V.S. (2014). Features of the structure of the root system of pine trees on soils with and without rocky rocks in Central Polissya. Forestry and gardening, 4, 1-7 (in Ukrainian).

Eshel, A., \& Beeckman, T. (2013). Plant Roots: The Hidden Half. Fourth Edition. Boca Raton: CRC Press.

Ganatsas, P., \& Spanos, I. (2005). Root system asymmetry of Mediterranean pines. Plant and Soil, 278,75-83. https://doi.org/10.1007/s11104-0051092-3

Helder, M., Strik, D.P.B.T.B., Hamelers, H. V.M., \& Buisman, C.J.N. (2012). The flat-plate plant microbial fuel cell: The effect of a new design on internal resistances. Biotechnology for Biofuels, 5 (1), 70. doi: 10.1186/1754-6834-5-70

Hroisman, V. (2017). Strategy to improve the mechanism to control the use and protection of agricultural land state property and disposal. Kyiv: Cabinet of Ministers of Ukraine (in Ukrainian). https://zakon. rada.gov.ua/laws/show/413-2017-\%D0\%BF

Hryhora, I. M., Vorobiov, Ye. O., \& Solomakha, V.A. (2005). Forest swamps of Ukrainian Polissya (origin, dynamics, classification). Kyiv: Fitosotsiotsentr (in Ukrainian).

Ilina, O.V. (2007). Volynia swamps: features of distribution and anthropogenic changes. Scientific works of the Ukrainian Hydrometeorological Research Institute, 256, 367-372 (in Ukrainian).

Ivchenko, A.S. (2007). Marshlands of Ukraine. In Great Atlas of the world. Geographic Encyclopedia. (pp. 333-336). Kyiv: Amerkom Ukraina (in Russian).

Kaku, N., Yonezawa, N., Kodama, Y., \& Watanabe, K. (2008). Plant/microbe cooperation for electricity generation in a rice paddy field. Applied Microbiology and Biotechnology, 79 (1), 43-49. https://doi. org/10.1007/s00253-008-1410-9

Kalinin, M. I., Huz, M. M., \& Debryniuk, I. M. (1998). Forest root science. Lviv: Ukrainian State Forestry University (in Ukrainian).

Kim, B.H., Park, H.S., Kim, H.J., Kim, G.T., Chang, I.S., J. Lee, \& Phung, N.T. (2004). Enrichment of microbial community generating electricity using a fuel-cell-type electrochemical cell. Applied Microbiology and Biotechnology, 63, 672681. https://doi.org/10.1007/s00253-003-1412-6

Kouzuma, A., Kaku, N., \& Watanabe, K. (2014). Microbial electricity generation in rice paddy fields: recent advances and perspectives in rhizosphere microbial fuel cells. Applied Microbiology and Biotechnology, 98 (23), 9521-9526. https://doi. org/10.1007/s00253-014-6138-0

Li, L., Du, Q., Ren, F., \& Ma, X. (2019). Assessing spatial accessibility to hierarchical Urban Parks by multi-types of travel distance in Shenzhen. China 
International Journal of Environmental Research and Public Health, 16 (1038), 1-23. https://doi. org/10.3390/ijerph16061038

Liu, S., Song, H., Li, X., \& Yang, F. (2013). Power generation enhancement by utilizing plant photosynthate in microbial fuel cell coupled constructed wetland system. International Journal of Photoenergy, Article ID 172010, 1-10. https://doi. org/10.1155/2013/172010

Logan, B.E., \& Regan, J.M. (2006). Electricityproducing bacterial communities in microbial fuel cells. Trends Microbiology, 14, 512-518. https://doi. org/ 10.1016/j.tim.2006.10.003

Logan, B.E., Rossi, R., Ragab, A., \& Saikaly, P.E. (2019). Electroactive microorganisms in bioelectrochemical systems. Nature Reviews Microbiology, 17 (5), 307-319. https://doi.org/10.1038/ s41579-019-0173-x

Lovley, D.R., Ueki, T., Zhang, T., Malvankar, N.S., Shrestha, P. M., Flanagan, K. ... Nevin, K.P. (2011). Geobacter: the microbe electric's physiology, ecology, and practical applications. Advances in Microbial Physiology, 59, 1-100. https://doi.org/10.1016/B9780-12-387661-4.00004-5

Lu, L., Xing, D., \& Ren, Z.J. (2015). Microbial community structure accompanied with electricity production in a constructed wetland plant microbial fuel cell. Bioresource Technology, 195, 115-121. https://doi.org/10.1016/j.biortech.2015.05.098

Maliuha, V.M., \& Khryk, V.M. (2010). The fastening properties of the root system of the pine tree on the ravine and girder lands. Scientific reports National University of Life and Environmental Sciences of Ukraine, 4 (20), 1-11 (in Ukrainian).

Mauer, O., Houskova, K., \& Mikita, T. (2017). The root system of pedunculate oak (Quercus robur L.) at the margins of regenerated stands. Journal of Forest Science, 63 (1), 22-33. https://doi. org/10.17221/85/2016-JFS

Mokriienko, V.A., \& Tsentylo, L. V. (2011). Features of growth and development of corn, depending on the time of sowing and density of plants. Scientific reports National University of Life and Environmental Sciences of Ukraine, 3 (25), 28-35 (in Ukrainian).

Munzenberger, B., Golldack, J., Ullrich, A., Schmincke, B., \& Huttl, R.F. (2004). Abundance, diversity, and vitality of mycorrhizae of Scots pine (Pinus sylvestris L.) in lignite recultivation sites. Mycorrhiza, 14 (3), 193-202. https://doi.org/10.1007/ s00572-003-0257-2

Nguyen, V., \& Nitisoravut, R. (2019). Bioelectricity generation in Plant Microbial Fuel Cell using forage grass under variations of circadian rhythm, ambient temperature, and soil water contents. 2019 IEEE Asia Power and Energy Engineering Conference, Chengdu, China, 240-244. https://doi.org/10.1109/ APEEC.2019.8720344

Ostonen, I., Rosenvald, K., Helmisaari, H.-S., Godbold, D., Parts, K., Uri, V., \& Lohmus K. (2013).
Morphological plasticity of ectomycorrhizal short roots in Betula sp and Picea abies forests across climate and forest succession gradients: its role in changing environments. Frontiers in Plant Science, 4, 335. https://doi.org/10.3389/fpls.2013.00335

Raudaskoski, M., \& Salo, V. (2008). Dichotomization of mycorrhizal and NPA-treated short roots in Pinus sylvestris. Plant Signaling \& Behavior, 3 (2), 113115. https://doi.org/10.4161/psb.3.2.4972

Rusyn, I.B., \& Medvediev, O.V. (2016). Biological method of producing bioelectricity from deep soil layers. Patent of Ukraine 112093, filed March 9, 2016, issued December 12, 2016 (in Ukrainian).

Strik, D. P.B. T.B., Hamelers, H. V. M., Snel, J. F.H., \& Buisman, C.J. (2008). Green electricity production with living plants and bacteria in a fuel cell. International Journal of Energy Research, 32 (9), 870-876. https://doi.org/10.1002/er.1397

Simard, S. W., Asay, A., Beiler, K. J., Bingham, M.A., Deslippe, J. R., He, X., ... Teste, F. P. (2015). Resource transfer between plants through ectomycorrhizal fungal networks. In Horton, T. R. (Ed.), Mycorrhizal Networks (Vol. 224, pp. 133-176). (Ecological studies: Analysis and Synthesis). Dordrecht: Springer.

Strik, D.P.B., T.B., Timmers, R.A., Helder, M., Steinbusch, K. J., Hamelers, H.V., \& Buisman, C.J. (2011). Microbial solar cells: applying photosynthetic and electrochemically active organisms. Trends in Biotechnology, 29 (1), 41-49. https://doi. org/10.1016/j.tibtech.2010.10.001

Sudirjo, E., Pim de Jager, Cees J. N., Buisman, C. J. N., \& Strik, D.P.B. T.B. (2019). Performance and Long Distance Data Acquisition via LoRa Technology of a Tubular Plant Microbial Fuel Cell Located in a Paddy Field in West Kalimantan. Indonesia Sensors, 19, 4647. https://doi.org/10.3390/s19214647

Takanezawa, K., Nishio, K., Kato, S., Hashimoto, K, \& Watanabe, K. (2010). Factors affecting electric output from rice-paddy microbial fuel cells. Bioscience, Biotechnology \& Biochemistry, 74, 1271-1273. https://doi.org/10.1271/bbb.90852

Timmers, R.A., Rothballer, M., Strik, D.P.B.T.B., Engel, M., Schulz, S., Schloter, M. ... B., \& Buisman, C. (2012). Microbial community structure elucidates performance of Glyceria maxima plant microbial fuel cell. Applied Microbiology \& Biotechnology, 94 (2), 537-548. https://doi.org/10.1007/s00253$012-3894-6$

Ueoka, N., Sese, N., Sue, M., Kouzuma, A., \& Watanabe, K. (2016). Sizes of Anode and Cathode Affect Electricity Generation in Rice PaddyField Microbial Fuel Cells. Journal of Sustainable Bioenergy Systems, 06 (01), 10-15. https://doi. org/10.4236/jsbs.2016.61002

Wetser, K.,Liu, J., Buisman, C. J. N., \& Strik, D. P. B. T. B. (2015). Plant microbial fuel cell applied in wetlands: Spatial, temporal and potential electricity generation of Spartina anglica salt marshes and Phragmites australis peat soils. Biomass \& Bioenergy, 83, 543550. https://doi.org/10.1016/j.biombioe.2015.11.006 
Wetser, K. (2016). Electricity from wetlands: Technology assessment of the tubular Plant Microbial Fuel Cell with an integrated biocathode. Part two: PMFCs applied in wetlands. Wageningen: Wageningen University. https://doi.org/10.1016/j. apenergy.2014.10.006

Zinchenko, O. I., Salatenko, V. N., \& Bilonozhko, M.A. (2001). Plant Growing. Kyiv: Agricultural education (in Ukrainian).

Zuzuk, B.M., Kutsyk, R.V., Radko, O.V., Kulahina, M.A., \& Serbin, A.H. (2007). Alder gray, alder white Alnus incana (L.) Moench. Magazine Pharmacist, 8, 1-10 (in Ukrainian).

\section{Биоэлектричество экосистем лесов, заболоченных лугов и агроэкосистем Западной Украины}

\author{
И.Б. Русын' , А.В. Медведев², Б.Т. Валько ${ }^{3}$, \\ С.В. Никитчук ${ }^{4}$
}

Получение биоэлектричества из экосистем живых растений с ассоциированными почвенными электрико-генерирующими микроорганизмами является инновационным источником альтернативной энергии. In situ проведена оценка биоэлектропродуктивности экосистем лесных массивов, болотистых территорий, агроэкосистем плодовых садов и насаждений сельско-хозяйственных культур в северной (Полесье), центральной (Ополье) и южной (на границе ПокутскоБуковинских Карпат и Черногоры) частях западного региона Украины. Биоэлектрический потенциал определялся в наиболее распространенных

Русын Ирина Богдановна - кандидат биологических наук, доцент кафедры экологии и сбалансированного природопользования Института устойчивого развития им. Вячеслава Чорновола. Национальный университет «Львовская Политехника», ул. Степана Бандеры, 12, г. Львов, 79013, Украина. Тел.: + 38098-435-67-01. E-mail: rib7@i.ua ORCID: http://orcid.org/00000002-6041-1245

Медведев Александр Валентинович - ведущий инженерконструктор филиала «Научно-исследовательский институт автомобилестроения “Эталон”», ул. Городоцкая, 174, Львов, 79022, Украина. Тел.: + 38-067-337-10-17. E-mail: mov2@ukr. net ORCID: https://orcid.org/0000-0002-0824-9893

Валько Богдан Тарасович - магистр кафедры экологии и сбалансированного природопользования Института устойчивого развития им. Вячеслава Чорновола. Национальный университет «Львовская Политехника», ул. Степана Бандеры, 12, г. Львов, 79013, Украина. Тел.: + 38-093-709-49-29. E-mail valkobogdan@mail.ru

4 Никитчук Сергей Викторович - магистр кафедры экологической безопасности и природоохранной деятельности Института устойчивого развития им. Вячеслава Чорновола. Национальный университет «Львовская Политехника», ул. Степана Бандеры, 12, г. Львов, 79013, Украина. Тел.: + 38-063-074-8531. E-mail: nikitchyk2015@i.ua типовых микробно-растительных ассоциациях лесных фитоценозов, заболоченных лугов и агроэкосистем с помощью двух-электродной системы, которую размещали стационарно в почве в зоне ассоциации корневой системы растений и электрико-генерирующих микроорганизмов в течение 150 дней (с начала лета до средины осени).

Наиболее высокие показатели биоэлектричества зафиксированы в фито-микробоценозах лесов. Средний уровень биоэлектрического потенциала в лесах составил 1080,5 мВ. В садах и заболоченных лугах биоэлектрические показатели были несколько ниже - 1055,3 и 1051,2 мВ соответственно. Биоэлектрический потенциал большинства агрокультур существенно ниже, кроме культуры Zea mays L., которая характеризовалась высокими средними значениями биоэлектрического потенциала на уровне садовых кустов. Установлено, что суточный уровень биоэлектричества в большей части образцов колеблется незначительно с несущественным снижением в конце светового дня. Сезонные колебания уровня биоэлектрического потенциала на протяжении июня - октября в исследованных микробнорастительных ассоциациях являются статистически незначительными. Исследовано влияние влажности на генерацию биоэлектрического потенциала фито-микробоценозами. Выявлено положительное влияние влажности почвы на генерирование биоэлектрического потенциала. Установлено увеличение биоэлектрического потенциала в сухих почвах, обусловленное активным фотосинтезом и аккумуляцией влаги растениями.

Высокие и стабильные средние значения биоэлектрического потенциала микробно-растительных ассоциаций лесов и заболоченных лугов, плодовых садов и некоторых сельскохозяйственных культур в период с июня по октябрь, увеличение биоэлектрического потенциала даже в засушливых условиях раскрывает его перспективы как важного источника возобновляемой энергии. Леса и заболоченные территории, которые занимают значительную часть территории Западной Украины, смогли бы стать дополнительным экологически чистым источником энергии, как масштабного, так и локального значения в случае дальнейшей разработки тех или иных аспектов электробиотехнологии.

Ключевые слова: растения; почвенные микроорганизмы; почва; биоэлектрический потенциал; биоэлектрохимическая энергия; электроды; возобновляемая энергетика. 


\section{Bioelectricity of forests ecosystems, wetlands and agro-ecosystems of the Western Ukraine}

\section{Rusyn', O. Medvediev², B. Valko3 , S. Nikitchuk ${ }^{4}$}

Bioelectricity from ecosystems of living plants and their associated soil electric-generating microorganisms is an innovative source of alternative energy. The bioelectro-productivity of forests ecosystems, marshy areas and agro-ecosystems of orchards and plantations of agricultural crops was assessed in situ in three parts of the Western Ukraine in the north, in the Polissia, in the central part, in the Opillia and in the south, on the border of the Pokutsko-Bukovina Carpathians and Chornogora. The bioelectric potential was determined in the most spread and typical microbial-plant associations of forests, swampy meadows and agro-ecosystems of the Western Ukraine using the two-electrode system, which was located stationary in the soil in the zone of association of the plant root system and electricgenerating microorganisms during 150 days - from the beginning of summer to late autumn.

The highest rates of bioelectricity were recorded in phyto-microbiocenoses of forests. The average level of bioelectric potential of forests was $1080.5 \mathrm{mV}$. In the gardens and wetlands, bioelectric performance was

Iryna Rusyn - PhD of Biological Sciences, Associate Professor of the Department of Ecology and Sustainaible Environmental Management, Viacheslav Chornovil Institute of Sustainable Development. Lviv Polytechnic National University, Stepan Bandera st., 12, Lviv, 79013, Ukraine. Phone: + 38-098-435-67-01. E-mail: rib7@i.ua ORCID: http://orcid.org/0000-0002-6041-1245

Oleksandr Medvediev - Leading Design Engineer of the Lviv Department of Automobile Research Institute Etalon, Horodotska st., 174, Lviv, 79022, Ukraine. Tel: + 38-067-337-10-17. E-mail: mov2@ukr.net ORCID: https://orcid.org/0000-0002-0824-9893

Bohdan Valko - Master of Ecology and Balanced Nature Management Department of Ecology and Sustainaible Environmental Management, Viacheslav Chornovil Institute of Sustainable Development. Lviv Polytechnic National University, Stepan Bandera st., 12, Lviv, 79013, Ukraine. Phone: + 38-093-709-49-29. E-mail: valkobogdan@mail.ru

${ }^{4}$ Serhii Nikitchuk - Master of Department of Ecological Safety and Nature Protection Activity, Viacheslav Chornovil Institute of Sustainable Development. Lviv Polytechnic National University, Stepan Bandera st., 12, Lviv, 79013, Ukraine. Phone: + 38-063074-85-31. E-mail: nikitchyk2015@i.ua slightly lower, $1055.3 \mathrm{mV}$ and $1051.2 \mathrm{mV}$, respectively. The bioelectric potential of the most agricultural crops was significantly lower, except for the $Z$. mays crop, which was characterized by high average values of bioelectric potential at the level of garden shrubs. It was found that the daily level of bioelectricity fluctuates slightly with slight decrease at the end of the light day in the some samples. We observed small fluctuations in the parameters of bioelectric potential, because the level of photosynthesis and, accordingly, the degree of accumulation of organic compounds that are substrates for the development of electroactive microorganisms, depending on meteorological conditions, physicochemical soil factors are specific to each ecosystem and each new day. The seasonal fluctuations in the level of bioelectric potential during June - October in the studied microbial-plant associations were statistically insignificant. The influence of humidity on the generation of the bioelectrical potential of phytomicrobocenoses was studied. The positive effect of soil moisture on the bioelectric potential generation was revealed. With increase in humidity of soil from $15 \%$ to $55 \%$ the level of bioelectric potential of forest and garden microbial-plant associations also increased significantly. The increasing of the bioelectric potential of forest and garden microbial-plant associations of $P$. silvestris and $M$. domestica was $159.3 \mathrm{mV}$ and $115.4 \mathrm{mV}$, respectively in these conditions. The increasing of bioelectric potential in dry soils was determined, due to active photosynthesis and moisture accumulation by plants. With the decrease in humidity of soil from $55 \%$ to $25 \%$, the level of bioelectric potential increased significantly in agricultural and garden microbial-plant associations of $R$. rubrum and $B$. oleracea, the increase in bioelectric potential was 96.3 and $81.7 \mathrm{mV}$, respectively.

High and stable average values of the bioelectric potential of microbial-plant associations of forests and wetland meadows, orchards and some crops observed for the period from June to October, the rise of potential even in arid conditions were revealed their prospects as an important source of renewable energy. Forests and wetlands, which occupy a significant part of the territory of Western Ukraine, could become an additional environmentally friendly source of energy, both large-scale and local in case of further development of electro-biotechnology.

Key words: plants; soil microorganisms; soil; bioelectric potential; bioelectrochemical energy; electrodes; renewable energy. 